\title{
Pengaruh Celebrity Endorser dan Media Sosial Youtube Sebagai Sarana Cyber Branding Terhadap Keputusan Pembelian Neo Coffee
}

\author{
Julia Stefani, Ahmad Junaidi \\ Juliaaastefani@gmail.com; ahmadd@fikom.untar.ac.id \\ Fakultas Ilmu Komunikasi Universitas Tarumanagara
}

\begin{abstract}
:
In a marketing environment, effective communication is the most important thing that can bring the company achieved a history of success. The companies compete with each other as well as to seek a variety of things to do to promote their brands. Some examples include using celebrity endorser and make social media as a means of cyber branding youtube to promote their products. Currently we are in the era of technology and communications are growing very fast and are not restricted by time and space. By doing so, consumers are also increasingly selective in their choice of products, respectively. This study aimed to determine the effect of celebrity endorser and YouTube social media as a means of cyber branding on purchase decisions Neo Coffee. The method used is quantitative research methods. The samples used in this study were 75 people who are members of the NCT fandom in Instagram. Analysis of the data in this study using Validity Test, Test The reliability, Normality Test, Test Multiple Regression Analysis and Testing Hypotheses. Based on this research, it was found that the existence of significant influence and a strong hubungan between celebrity endorser and YouTube social media on purchasing decisions Neo Coffee.
\end{abstract}

Keywords: celebrity endorser, purchase decision.

\begin{abstract}
Abstrak
Dalam lingkungan pemasaran, komunikasi yang efektif merupakan hal terpenting yang dapat membawa perusahaan mencapai suatu kesuksesan. Perusahaan-perusahaan saling bersaing satu sama lain serta mengupayakan berbagai macam hal yang dapat dilakukan demi mempromosikan merek mereka. Beberapa contoh diantaranya adalah dengan menggunakan celebrity endorser dan menjadikan media sosial youtube sebagai sarana cyber branding untuk mempromosikan produk mereka. Saat ini kita sedang berada di dalam era teknologi dan komunikasi yang berkembang sangat cepat serta tidak dibatasi oleh ruang dan waktu. Dengan begitu, konsumen juga semakin selektif dalam menentukan produk pilihan mereka masing- masing. Penelitian ini memiliki tujuan untuk mengetahui pengaruh celebrity endorser dan media sosial youtube sebagai sarana cyber branding terhadap keputusan pembelian Neo Coffee. Metode penelitian yang penulis gunakan merupakan metode penelitian kuantitatif. Jumlah sampel yang penulis gunakan dalam penelitian ini sebanyak 75 orang yang merupakan anggota fandom NCT di Instagram. Analisis data yang digunakan penulis pada penelitian ini menggunakan Uji Validitas, Uji Reliabilitas, Uji Normalitas, Uji Analisis Regresi Berganda, dan Uji Hipotesis. Berdasarkan hasil penelitian yang telah diteliti, ditemukan bahwa adanya pengaruh signifikan dan hubungan yang kuat antara celebrity endorser dan media sosial youtube terhadap keputusan pembelian Neo Coffee.
\end{abstract}

Kata Kunci : celebrity endorser, keputusan pembelian. 


\section{Pendahuluan.}

Dalam lingkungan pemasaran, perusahaan-perusahaan saling bersaing satu sama lain serta mengupayakan berbagai macam hal yang dapat dilakukan demi mempromosikan merek mereka. Pada umumnya, upaya-upaya yang dilakukan memiliki tujuan untuk menarik pelanggan dan menanamkan brand awareness di benak pelanggan. Setelah itu, pelanggan terdorong untuk mencoba dan memutuskan untuk membeli produk tersebut.

Tanpa kita sadari saat ini sudah banyak merek yang berada di sekitar kita dan tentunya datang dengan misi dan tujuan yang berbeda-beda. Kemudian merek-merek tersebut biasanya membedakan diri mereka dengan merek-merek lainnya agar memiliki keunikan tersendiri. Seluruh kegiatan hingga proses memperkenalkan merek kepada setiap orang dinamakan branding. "Branding sendiri merupakan nama, istilah, tanda, simbol atau rancangan atau kombinasi dari semua yang di maksud untuk mengidentifikasikan barang atau jasa atau kelompok penjual dengan tujuan untuk mendiferensiasikannya "membedakan" dari barang atau jasa para pesaing." (Kotler, 2009).

Dahulu branding hanya dapat dituangkan ke dalam media konvensional seperti iklan di brosur, billboard, pembuatan flyer, spanduk, iklan di koran, serta pembuatan iklan di radio dan televisi. Akan tetapi, saat ini pemanfaatan media sosial sebagai media alternatif untuk mengkomunikasikan pesan-pesan pemasaran semakin massif (Pandrianto dan Sukendro, 2018). Dengan berkembangnya teknologi seperti sekarang ini, proses branding dapat dilakukan jauh lebih mudah dan lebih efektif dengan munculnya internet dan media sosial. Salah satu contohnya adalah proses branding menggunakan media sosial youtube juga merupakan senjata paling ampuh untuk memperkenalkan suatu merek kepada dunia yang cakupannya lebih besar yang tidak dibatasi oleh ruang dan waktu.

Selain itu, banyaknya jumlah pesaing juga membuat perusahaan memiliki cara tersendiri untuk mempersiapkan strategi komunikasi yang paling efektif dalam beriklan. Salah satu contoh cara yang paling efektif serta kreatif dalam beriklan adalah dengan cara menggunakan celebrity endorser yang merupakan seseorang pribadi yang sangat dikenal oleh publik dan menjadi pujaan. Digunakan untuk menyampaikan pesan iklan, memiliki maksud untuk menarik perhatian dan mempengaruhi konsumen sasaran

Tren minum kopi dan tingginya permintaan konsumen terhadap kopi memiliki dampak positif bagi para pelaku bisnis. Saat ini, perusahaan Wingsfood Indonesia telah meluncurkan kopi bubuk baru yang diberi nama Neo Coffee. Strategi yang dilakukan oleh Wings food dalam memperkuat brand kopi tersebut adalah dengan cara menggunakan artis Korea yang berasal dari China, yaitu Lucas WayV sebagai celebrity endorser dari produk Neo Coffee. Disamping itu, Indonesia juga merupakan salah satu negara yang memiliki jumlah fans Korea tertinggi di dunia.

Latar belakang tersebut merupakan alasan penulis dalam memilih topik sebagai fokus penelitian dengan judul "Pengaruh Celebrity Endorser Lucas NCT dan Penggunaan Media Sosial(Youtube) Sebagai Sarana Cyber Branding Terhadap Keputusan Pembelian Neo Coffee". 


\section{Metode Penelitian.}

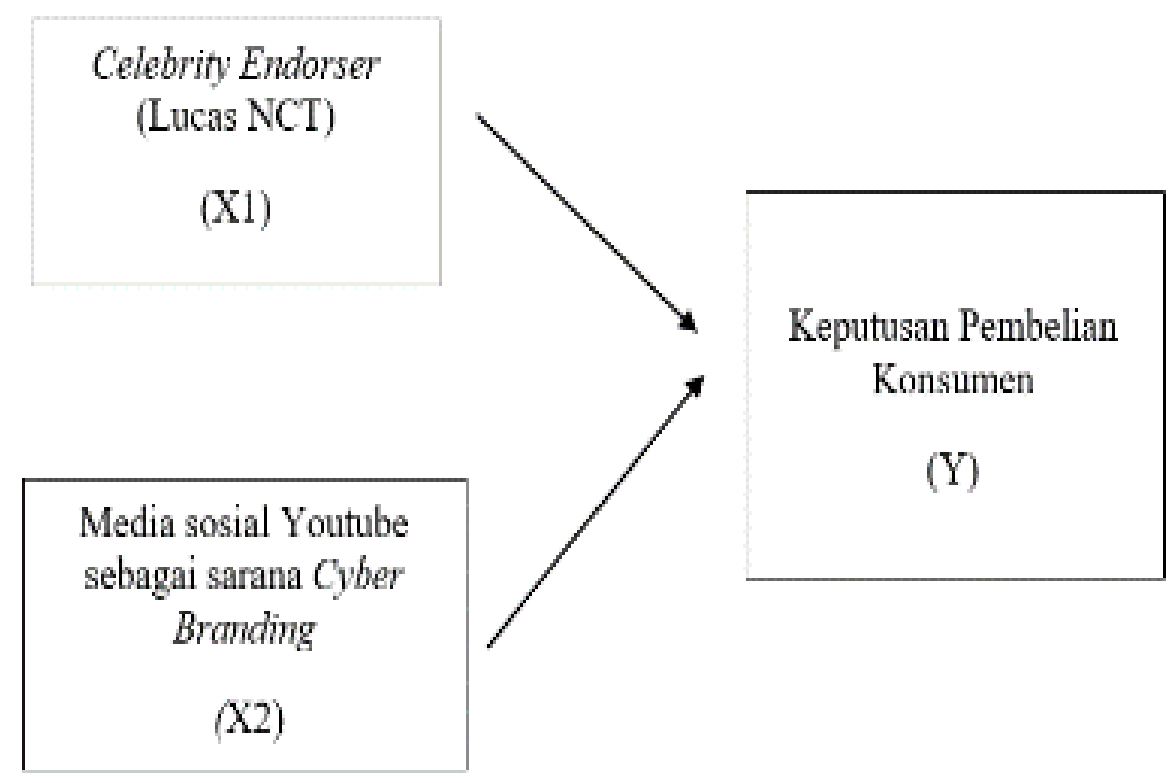

Gambar 1 : Kerangka Pemikiran

Metode yang digunakan penulis dalam melakukan penelitian ini adalah dengan pendekatan kuantitatif. Teknik pengumpulan yang digunakan oleh peneliti adalah dengan cara menggunakan kuesioner. Kuesioner tersebut berisikan pertanyaan-pertanyaan seputar celebrity endorser, media sosial youtube sebagai sarana cyber branding, dan keputusan pembelian. Kemudian kuesioner tersebut disebarkan kepada salah satu grup penggemar NCT yang akan diambil sampelnya sebanyak 75 orang. Variabel bebas dalam penelitian ini adalah celebrity endorser dan media sosial youtube. Sedangkan variabel terikatnya adalah keputusan pembelian.

Pengukuran dilakukan menggunakan skala Likert yang setiap pertanyaan atau pernyataan dihubungkan dengan jawaban yang berupa dukungan atau pernyataan sikap yang diungkapkan dengan kata-kata: (5) Sangat Setuju (ST),(4) Setuju (S), (3) Netral (N), (2) Tidak Setuju (TS), (1) Sangat Tidak Setuju (STS). Pada penelitian ini, yang menjadi populasi penelitian adalah seluruh anggota atau pengikut dari akun Instagram @ nct_support. Kemudian peneliti mengambil sampel sebanyak 75 orang dengan menggunakan rumus Hair, yaitu indikator dikali 5. 


\section{Analisis dan Pembahasan.}

\section{Uji Validitas.}

Tabel 1 : Hasil Uji Validitas

\begin{tabular}{|c|c|c|}
\hline & & $\mathrm{X} 1$ \\
\hline $\mathrm{Al}$ & $\begin{array}{l}\text { Pearson } \\
\text { Correlation } \\
\text { Sig. (2-tailed) } \\
\mathrm{N}\end{array}$ & $\begin{array}{r}.423^{* *} \\
.000 \\
75 \\
\end{array}$ \\
\hline$\Lambda 2$ & $\begin{array}{l}\text { Pearson } \\
\text { Correlation } \\
\text { Sig. (2-tailed) } \\
\mathrm{N}\end{array}$ & $\begin{array}{r}.763^{*-} \\
.000 \\
75\end{array}$ \\
\hline $\mathrm{A}^{3}$ & $\begin{array}{l}\text { Pearson } \\
\text { Correlation } \\
\text { Sig. (2-tailed) } \\
\mathrm{N}\end{array}$ & $\begin{array}{r}.711^{*+} \\
.000 \\
75 \\
\end{array}$ \\
\hline A4 & $\begin{array}{l}\text { Pearson } \\
\text { Correlation } \\
\text { Sig. (2-tailed) } \\
\mathrm{N}\end{array}$ & $\begin{array}{r}.700^{* 1} \\
.000 \\
75 \\
\end{array}$ \\
\hline A5 & $\begin{array}{l}\text { Pearson } \\
\text { Correlation } \\
\text { Sig. (2-tailed) } \\
\mathrm{N}\end{array}$ & $\begin{array}{r}.651^{* t} \\
.000 \\
75\end{array}$ \\
\hline A6 & $\begin{array}{l}\text { Pearson } \\
\text { Correlation } \\
\text { Sig. (2-tailed) } \\
\mathrm{N}\end{array}$ & $\begin{array}{r}.767^{*+} \\
.000 \\
75\end{array}$ \\
\hline A7 & $\begin{array}{l}\text { Pearson } \\
\text { Correlation } \\
\text { Sig. (2-tailed) } \\
\text { N }\end{array}$ & $\begin{array}{r}.493^{*+} \\
.000 \\
75\end{array}$ \\
\hline
\end{tabular}

\begin{tabular}{|c|c|c|}
\hline \multirow{2}{*}{ Bt } & & $\mathrm{X}_{2}$ \\
\hline & $\begin{array}{l}\text { Pearson Conrelation } \\
\text { Sig. (2-tailed) } \\
\mathrm{N}\end{array}$ & $\begin{array}{r}.482^{4} \\
.000 \\
75\end{array}$ \\
\hline \multirow[t]{2}{*}{ B2 } & $\begin{array}{l}\text { Pearson Conrelation } \\
\text { Sig, (2-tailed) }\end{array}$ & $\begin{array}{r}.630^{-4} \\
.000 \\
\end{array}$ \\
\hline & $\mathrm{N}$ & 75 \\
\hline $\mathrm{B} 3$ & $\begin{array}{l}\text { Pearson Conzelation } \\
\text { Sig. (2-railed) } \\
\text { N }\end{array}$ & $\begin{array}{r}.722^{24} \\
.000 \\
75\end{array}$ \\
\hline B4 & $\begin{array}{l}\text { Pearson Conrelation } \\
\text { Sig. (2-tailed) } \\
\text { N }\end{array}$ & $\begin{array}{r}.761^{27} \\
.000 \\
75 \\
\end{array}$ \\
\hline B5 & $\begin{array}{l}\text { Pearson Contelation } \\
\text { Sig. (2-tailed) } \\
\text { N }\end{array}$ & $\begin{array}{r}.666^{\circ} \\
.000 \\
75 \\
\end{array}$ \\
\hline Bo & $\begin{array}{l}\text { Penrson Conclation } \\
\text { Sig. (2-tniled) } \\
\text { N }\end{array}$ & $\begin{array}{r}.599^{\prime \prime} \\
.000 \\
75 \\
\end{array}$ \\
\hline B7 & $\begin{array}{l}\text { Pesarson Comelation } \\
\text { Sig. (2-tailed) } \\
\text { N }\end{array}$ & $\begin{array}{r}.367^{\circ} \\
.001 \\
75 \\
\end{array}$ \\
\hline B8 & $\begin{array}{l}\text { Pearson Conrelation } \\
\text { Sig. (2-tailed) } \\
\text { N }\end{array}$ & $\begin{array}{r}.645^{* 1} \\
.000 \\
75\end{array}$ \\
\hline B9 & $\begin{array}{l}\text { Pearson Conrelation } \\
\text { Sig. (2-lailed) } \\
\text { N }\end{array}$ & $\begin{array}{r}804^{+4} \\
.000 \\
75\end{array}$ \\
\hline
\end{tabular}

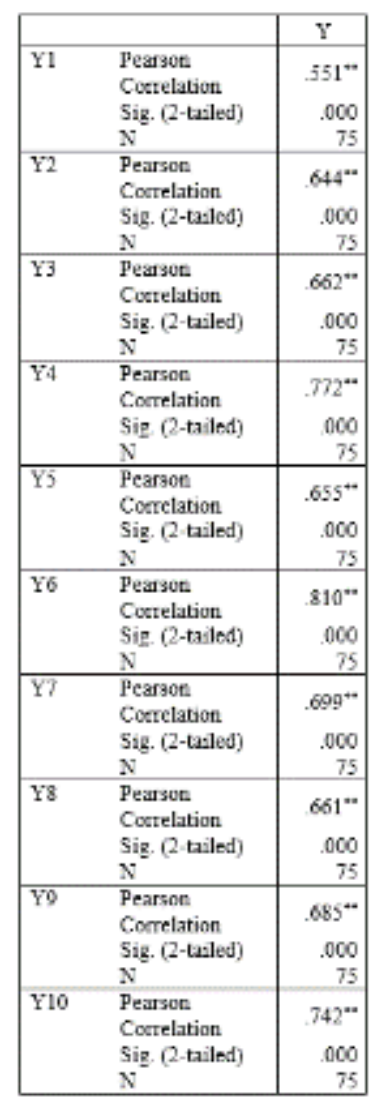

Dari hasil uji validitas diatas diketahui bahwa signifikansi dari seluruh pertanyaan memiliki nilai dibawah 0,05 . Sehingga dapat dinyatakan lolos pengujian validitas.

\section{Uji Reliabilitas.}

Untuk melakukan perhitungan Alpha penulis menggunakan alat bantu aplikasi program komputer, yaitu SPSS. Kemudian dalam pengambilan keputusan reliabilitas, 'hasil pengujian reliabilitas suatu instrumen alat ukur dapat dinyatakan reliabel jika memiliki nilai Cronbach's Alpha lebih dari 0,7' (Ghozali, 2012).

Tabel 2 : Hasil Uji Reliabilitas

\begin{tabular}{|c|c|c|}
\hline Variabel & Cronbach's Alpha & Keterangan \\
\hline $\mathrm{X} 1$ & .748 & Reliable \\
\hline $\mathrm{X} 2$ & .817 & Reliable \\
\hline $\mathrm{Y}$ & .864 & Reliable \\
\hline
\end{tabular}

(Sumber: Data Primer, Diolah dengan SPSS) 
Tabel diatas menunjukan bahwa hasil uji reabilitas dari variabel X1, X2, dan $\mathrm{Y}$ reliable hal itu dikarenakan memiliki angka yang lebih besar dari 0,600. Hal tersebut dapat dilihat bahwa variabel X1 memiliki nilai cronbach alphanya sebesar 0,748, variabel X2 memiliki nilai sebesar 0,817 , dan variabel $\mathrm{Y}$ memiliki nilai sebesar 0,864 .

\section{Uji Asumsi Klasik.}

\section{Uji Normalitas.}

Tabel 3 : Hasil Uji Normalitas

\begin{tabular}{|c|c|c|c|}
\hline Yadiabel & A-sig & batas & Keterangan \\
\hline $\mathrm{X} 1$ & 0,677 & $>0,05$ & Terdistribusi Normal \\
\hline $\mathrm{X} 2$ & 0,815 & $>0,05$ & Terdistribusi Normal \\
\hline $\mathrm{Y}$ & 0,749 & $>0,05$ & Terdistribusi Normal \\
\hline
\end{tabular}

Hasil dari uji normalitas dapat dikatakan terdistribusi secara normal apabila probabilitasnya $>0,05$. Berdasarkan tabel diatas diketahui bahwa nilai Asymtotic Significance sebesar $0,000<0,05$, sehingga dapat disimpulkan bahwa datanya berdistribusi normal.

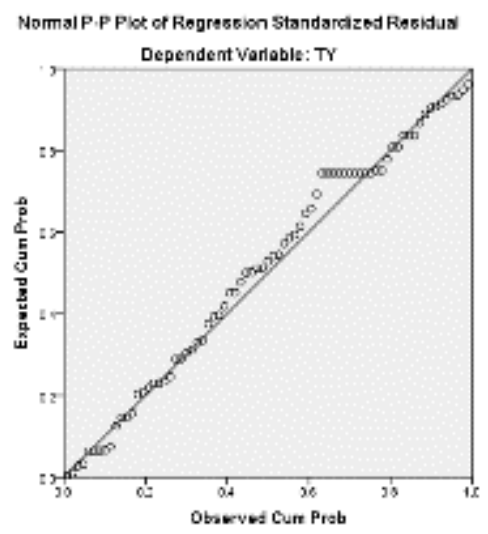

Gambar 1 : Grafik Hasil Uji Normalitas.

\section{Uji Heteroskedastisitas.}

Uji heterokedastisitas ditujukan untuk menguji apakah model regresi terjadi ketidaksamaan variance dari residual yang ada (Ghozali, 2012). 
Tabel 4 : Uji Heteroskedastisitas.

\begin{tabular}{|l|c|c|c|}
\hline Variabel & sig & Batas & Keterangan \\
\hline $\mathrm{X} 1$ & 0,058 & $>0,05$ & Tidak terjadi heterokedasitas \\
\hline $\mathrm{X} 2$ & 0,698 & $>0,05$ & Tidak terjadi heterokedasitas \\
\hline
\end{tabular}

Hasil uji heteroskedastisitas dapat dilihat berdasarkan nilai signifikansinya (Ghozali, 2012:), yaitu :

a. Jika nilai signifikansinya $>0,05$ maka tidak terjadi gejala heteroskedastisitas.

b. Jika nilai signifikansinya $<0,05$ maka terjadi gejala heteroskedastisitas.

Berdasarkan tabel 4 diketahui bahwa nilai probabilitasnya lebih besar dari 0,05 , dengan demikian kedua variabel $\mathrm{X}$ yang diajukan dalam penelitian ini tidak terjadi gejala heteroskedasitas.

\section{Uji Multikolinearitas}

Uji multikolinieritas memiliki tujuan untuk melihat apakah dalam model regresi ditemukan adanya korelasi antar variabel bebas yang ada.

Tabel 5 :Hasil Uji Multikolinearitas

\begin{tabular}{|l|c|c|c|}
\hline Variabel & Tolerance & VIF & Keterangan \\
\hline $\mathrm{X} 1$ & 0,938 & 1,066 & Tidak terjadi multikolinieritas \\
\hline $\mathrm{X} 2$ & 0,938 & 1,066 & Tidak terjadi multikolinieritas \\
\hline
\end{tabular}

Hasil pengukuran uji multikolinieritas dapat dikategorikan sebagai berikut (Ghozali, 2012:106):

a. Jika nilai tolerance nya $>0,10$ dan VIF $<10$ maka tidak terjadi multikolinieritas.

b. Jika nilai tolerance nya $<0,10$ dan VIF $>10$ maka terjadi multikolinieritas.

Berdasarkan tabel 5 dapat diketahui bahwa pada variabel X1 dan X2 di penelitian memiliki nilai tolerance valuenya $>0,10$ atau nilai VIF $<10$ sehingga tidak terjadi multikolinieritas. 


\section{Analisis Regresi Berganda}

\section{Koefisien Determinasi $\left(\mathbf{R}^{2}\right)$}

Tabel 6 :

Koefisien

determinasi

\begin{tabular}{|l|l|r|r|r|}
\hline Model & R & R Square & $\begin{array}{c}\text { Adjusted R } \\
\text { Square }\end{array}$ & $\begin{array}{c}\text { Std. Error of } \\
\text { the Estimate }\end{array}$ \\
\hline 1 & $.679^{\mathrm{a}}$ & .462 & .447 & 3.733 \\
\hline
\end{tabular}

\section{a. Predictors: (Constant), X2, X1}

Tabel 6 menunjukkan bahwa nilai koefisien determinasi variabel independen Celebrity Endorser dan Media sosial Youtube sebagai sarana Cyber Branding menjelaskan variabel dependen Keputusan Pembelian Konsumen memiliki nilai sebesar sebesar 44,7\%, dimana hal ini dilihat berdasarkan nilai Adjusted R Square hasil pengujian sebesar 0,447. Hasil ini menunjukan bahwa sebesar 55,3\% yang menjabarkan variabel dependen (Y) merupakan faktor-faktor lain yang tidak dijelaskan dalam penelitian ini $(\varepsilon)$.

\section{Uji Signifikansi Simultan (Uji F).}

Tabel 7:

Hasil Uji

$\mathrm{F}$

\begin{tabular}{|l|l|r|r|r|c|c|}
\hline \multicolumn{2}{|l|}{ Model } & Sum of Squares & df & Mean Square & F & Sig. \\
\hline \multirow{4}{*}{$1 \quad$ Regression } & 860.419 & 2 & 430.209 & 30.865 & $.000^{\circ}$ \\
\cline { 2 - 8 } & Residual & 1003.581 & 72 & 13.939 & & \\
\cline { 2 - 8 } & Total & 1864.000 & 74 & & & \\
\hline
\end{tabular}

Table 7 menunjukan berdasarkan ketentuan uji $\mathrm{F}$ dimana nilai signifikansinya $\leq 0,05$, maka dapat dikatakan bahwa Celebrity Endorser dan Media sosial Youtube sebagai sarana Cyber Branding memiliki pengaruh yang signifikan terhadap Keputusan Pembelian Konsumen. 


\section{Uji Hipotesis (Uji T).}

Tabel 8 : Hasil Uji T

\begin{tabular}{|l|c|c|c|}
\hline \multicolumn{1}{|c|}{ Variabel } & $B$ & Sig & Keterangan \\
\hline (Constant) & $-7,999$ & 0,257 & - \\
\hline $\mathrm{X} 1$ & 1,244 & 0,000 & Memiliki Pengaruh \\
\hline $\mathrm{X} 2$ & 0,295 & 0,023 & Memiliki Pengaruh \\
\hline
\end{tabular}

Berdasarkan uji hipotesis pada tabel 8, untuk variabel celebrity endorser (x1) diperoleh koefisien regresi $(\beta)$ 1,244 dengan nilai signifikansinya sebesar 0,000 . Hasil analisis menunjukkan bahwa nilai signifikansi $(\mathrm{sig})<0,05$, maka memiliki kesimpulan bahwa variabel celebrity endorser memiliki pengaruh terhadap keputusan pembelian konsumen. Untuk variabel media sosial youtube sebagai sarana cyber branding $(\mathrm{x} 2)$ diperoleh koefisien regresi $(\beta)$ 0,295 dengan nilai signifikansi sebesar 0,023. Hasil analisis menunjukkan bahwa nilai signifikansinya $($ sig $)<0,05$, maka dapat disimpulkan bahwa variabel media sosial youtube sebagai sarana cyber branding memiliki pengaruh terhadap keputusan pembelian konsumen. Dari kedua hal tersebut, maka dapat disimpulkan bahwa keputusan pembelian konsumen dipengaruhi oleh variabel celebrity endorser dan media sosial youtube sebagai sarana cyber branding. Sehingga pada penelitian ini didapatkan kesimpulan bahwa hipotesis terdukung (Ha1).

\section{Simpulan.}

Penelitian ini mempunyai tujuan untuk mengetahui pengaruh celebrity endorser dan penggunaan media sosial youtube sebagai sarana cyber branding terhadap keputusan pembelian Neo Coffee. Dalam penelitian ini, peneliti menggunakan uji validitas, reliabilitas, normalitas, dan analisis regresi berganda.

Dalam penelitian ini semua variabel dinyatakan valid dan reliabel. Maka dapat ditarik kesimpulan sebagai berikut:

Berdasarkan hasil penelitian, penulis mendapatkan hasil bahwa terdapat pengaruh antara variabel celebrity endorser (X1) dan variabel media sosial (X2) terhadap variabel keputusan pembelian (Y). Variabel celebrity endorser (X1) dan variabel media sosial (X2) mempengaruhi keputusan pembelian sebesar 44,7\%. Kemudian sebesar 55,3\% yang menyebutkan bahwa variabel keputusan (Y) dipengaruhi oleh faktor-faktor lainnya yang tidak penulis bahas di dalam penelitian ini. 
Julia Stefani, Ahmad Junaedi: Pengaruh Celebrity Endorser dan Media Sosial Youtube Sebagai Sarana Cyber Branding Terhadap Keputusan Pembelian Neo Coffee

\section{Ucapan Terimakasih.}

Pada kesempatan ini, penulis ingin mengucap syukur kepada Tuhan Yang Maha Esa dan juga orang-orang yang mendukung penulis sehingga penulis dapat menyelesaikan skripsi yang berjudul "Pengaruh Celebrity Endorser dan Media Sosial Youtube Sebagai Sarana Cyber Branding Terhadap Keputusan Pembelian Neo Coffee" tepat pada waktunya.

\section{Daftar Pustaka}

Ghozali, Imam. (2012). Aplikasi Analisis Multivariate dengan Program IBM SPSS.

Kotler dan Keller. 2009. Manajemen Pemasaran. Jilid 1, edisi ke 3. Jakarta : Erlangga.

Pandrianto, Nigar., dan Sukendro, Gregorius Genep. (2018). Analisis Strategi Content Pesan Marketing Untuk Mempertahankan Brand Engagement. Jurnal Komunikasi 10(2) 